\title{
FOUR TIMES “CONTRA": THE SOVIET, AMERICAN, DEMOCRATIC, AND EMIGRANT MODELS OF DANCING THE BULGARIAN WAY
}

\author{
GERGANA PANOVA-TEKATH
}

The urban interest in traditional Bulgarian dances constructed different communal realities in Bulgaria and abroad before and after 1989. The author discerns subtle protest in dancing the Bulgarian way and elaborates the meaning of this resistance in four contexts, whereby even the Soviet period is analyzed with great nuance. The phenomenon is defined as a reflexive expression of identity that allows fluid concepts of nationality. It persists as a survival strategy even during this pandemic. Keywords: urban folk dances, fluid nationality, intercultural communication, socialism, gentle protest, reflexive authenticity
Urbano zanimanje za tradicionalne bolgarske plese je oblikovalo različne resničnosti v Bolgariji in v tujini pred in po letu 1989. Avtorica razkriva subtilne proteste v bolgarkem načinu plesanja; pomen upora razloži s štirimi različnimi konteksti, posebej niansirano pa analizira sovjetsko obdobje. Ples kot pojav je opredeljen kot refleksivni izraz identitete, ki omogoča fluidno narodno pripadnost, in je zdaj v času epidemije tudi ena od pomembnih preživetvenih strategij. Ključne besede: urbani ljudski plesi, fluidna narodna pripadnost, medkulturna komunikacija, socializem, nežen protest, refleksivna pristnost

I have devoted much of my attention over the past twenty-five years at the Bulgarian Academy of Sciences to the study of the dissemination of Bulgarian traditional dances in modern urban centers in my homeland and abroad. I have defined this phenomenon as "dancing the Bulgarian way" by Bulgarians and foreigners, and have used it in my theoretical work on intra- and intercultural nonverbal communication. I analyze communicative constructions of reality based on my empirical examples and their models. Several years ago, I discovered that my analysis and interpretations were similar to the communicative constructivism proposed by Hubert Knoblauch, Reiner Keller, and Joe Reichertz (Keller et al. 2013). Consistent with their research approach, which is interdisciplinary, and aware of contemporary scholarly challenges, ${ }^{1}$ I continue to emphasize the role of the human body in the creation, development, transmission, and transformation of culture.

\section{MODELS OF DANCING THE BULGARIAN WAY}

The concepts presented here can be contextualized by two basic factors - one related to the place of occurrence (Bulgaria or abroad) and the other related to timing (before or after 1989). When combined, they delineate four models of dancing the Bulgarian way: the

1 Combining the theories of German phenomenology (Husserl, Schütz), American pragmatism (Peirce, Mead) and French poststructuralism (Foucault), paying attention to physical issues and behavior, considering the structuring in the discourse processes, and changing the concept of communication from understanding to effect. 
Soviet and democratic models in my homeland, and the American and emigrant models occurring abroad. Each of these four models has been the subject of individual studies (see, e.g. Panova-Tekath 2015), but I focused on the element of protest inherent to all of them for the first time when addressing the first international conference of the Dance Studies Association in Malta. ${ }^{2}$

Dancing is an affirmation of life, as several psychological studies and neurological experiments have shown. ${ }^{3}$ When people dance, they activate not only the sensory and motor circuits of their brains, but also the pleasure centers. However, dancing cannot simply be reduced to brain chemistry and the release of endorphins while performing in a social context. Through muscular bonding (McNeill 1997), group dances allow people to intimately feel part of a community and transmit power. The circle dance, which is also the prevalent form in Bulgarian folklore, is often used as a metaphor of peace. The circle creates a fulcrum for a particular collective identity. The experience of dancing together in a circle also affirms a negation and correlates with a rejection of something or somebody different (e.g., another group of different ethnicity). The specific dance creates an "insider" circle and communicates very gently a kind of "counterstatement" to the outside world: "we are us, not them." This is the momentum with which the authenticity of a dancer becomes reflexive. Moving clearly connects with thinking, and social dancing transforms into an intentional intercultural communication. Nevertheless, the resistance in the phenomenon that I elaborate is not obvious or predominant. It remains subtle and requires thorough qualitative research. I call it "gentle protest."

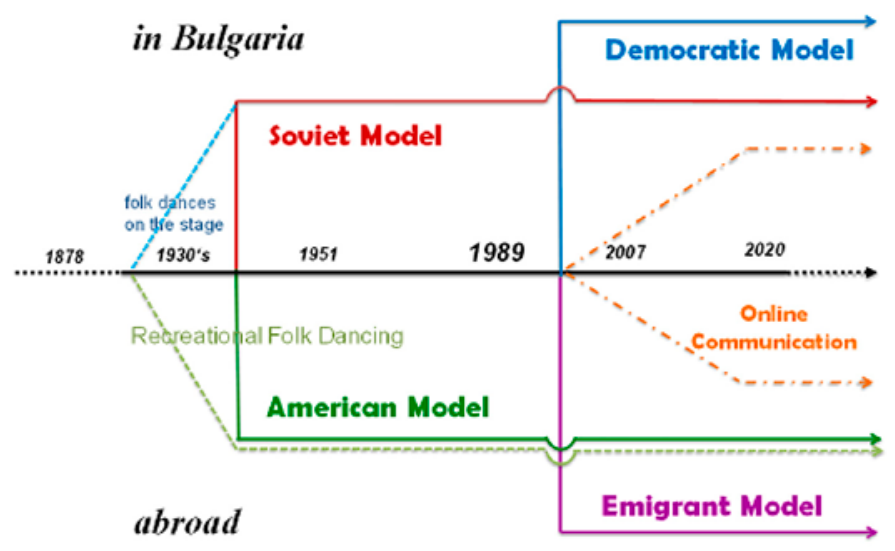

The four models of "dancing the Bulgarian way" in Bulgaria and abroad by time period.

2 https://dancestudiesassociation.org/conferences/contra-dance-conflict.

3 E.g., Research from Columbia University, University of Derby, University of Örebro, Deakin University, and New York University, and others. 
In a modern sense, dancing the Bulgarian way is a free and conscious decision to participate in groups and events, but not everyone initially recognizes that it is also a choice of cultural identity. However, the body is always authentic, and it continually expresses personality. Identities are very often in transition today; therefore, I investigate the phenomenon of dancing the Bulgarian way both as an interpretation of culture and a culture in itself. In order to explain the creative process of constructing identity and culture through traditional dancing, I use the philosophical theories of Charles S. Peirce and Ernst Cassirer (Cassirer 2010). In this vein I have also developed the term "reflexive authenticity" to emphasize the connection between acting and reflecting in dance. As a category of consciousness, dancing the Bulgarian way is not simply a feeling and passive quality without recognition or analysis (Firstness). ${ }^{5}$ Being a corporal act, it makes external certain facts and carries a sense of resistance to the temporal and spatial context. It is an authentic reaction to something or somebody and can interrupt historical lines or change the environment (Secondness). Then there are also definitions, manipulations, and learning processes through dance. In the framework of intra- and intercultural communication, dancing the Bulgarian way forms a symbolic Thirdness and can be interpreted as a political statement. Once the dancers link their activities to thoughts and goals and develop reflexive authenticity, they become able to limit and control the instrumentalization of the phenomenon. There is a dialectical relationship between symbolism and political power and a gentle transformative quality in "folk" dancing. ${ }^{6}$ I would like to clarify these through participative methods on a personal and collective level in the four models of the phenomenon.

The purpose of this article is to answer the following questions: what were/are the main variations of self-delineation by dancing the Bulgarian way, and what were/are their contextual backgrounds, argumentations, and effects?

\section{THE SOVIET MODEL: EVOLVED AS A “CONTRA-ART” IN THE ERA OF THE COLD WAR AND EAST-WEST CONFRONTATION}

Bulgaria has a century of experience in the presentation of dance folklore on international scenes as an instrument for self-proclamation. Bulgaria's traditional dance was rationalized as an attractive and distinctive mark of its national cultural identity as early as the

4 My use of this term was inspired by Alessandro Ferrara (1998) and I subsequently developed it further (Panova-Tekath 2005, 2011: 118-163, 2015).

5 The terms used here (e.g., firstness, secondness, thirdness) are from Charles S. Peirce's phenomenology: "It seems that the true categories of consciousness are first, feeling . . . [a] passive consciousness of quality, without recognition or analysis; second, consciousness of interruption . . . a sense of resistance, of an external fact ... ; third, synthetic consciousness, ... [a] sense of learning, thought" (Buchler 2014: 200).

6 Quotation marks are used for "folk" in order to underline its constructed character. 
1930s, when well-respected Bulgarian musicologists called on their countrymen to stop imitating the West and turn to our own rich traditions in all areas of music and dance arts (e.g., Djudjev 1932: 100).

After 1945, communist rule in Bulgaria initiated a massive movement for the revival, support, development, and popularization of the national dance heritage. In Bulgarian towns thousands of children, teenagers, and adults learned to dance "folk" dances in schools and participated enthusiastically in amateur ensembles. The channeling of this urban interest in folklore was perfected after 1951 when, following the Russian example, the Communist Party decided to establish the first state-owned ensemble for folk songs and dances in the capital, Sofia. ${ }^{7}$ During the next years in the small country of Bulgaria, another nineteen professional companies and several elite academies were formed. Compared to fascist Germany, Austria, and Italy, it is remarkable that an entirely new genre of stage art emerged in totalitarian Bulgaria and gradually evolved into a folklore dance theatre. ${ }^{8}$ Dozens of very talented choreographers and hundreds of highly educated dance teachers were supported and contributed to making these times the "Golden Years" of the genre (Panova-Tekath 2018).

During this time, both the expression of Bulgarian national identity and the Party agenda were advanced by the popularization of "folk" dancing and performance ensembles. In related subject areas, major American researchers such as Timothy Rice, Anthony Shay, and Donna Buchanan point explicitly to the connection between artificial symbolism and political power in the communist era. ${ }^{9}$ I am convinced that understanding this relationship (cf. Parkin 1996) is indispensable for decoding the Soviet model of dancing the Bulgarian way. It helps to explain the transformation of traditional practice into elite art and its influence on the entire contemporary Bulgarian culture. ${ }^{10}$ Fortunately, increasing numbers of Bulgarian scholars are now studying the communist past and the specific development of music and dance. ${ }^{11}$ In a collective publication from 2018 in Great Britain,

7 This group is today called the Philip Koutev National Folk Ensemble.

8 I have devoted a large part of my dissertation and a special research project to the analysis and comparison of folk choreography in various totalitarian regimes and the crises of national identity after their collapses (Panova-Tekath 2010, 2011).

9 Timothy Rice focused crucial theoretical works on Bulgarian music (e.g., Rice 2004), Donna Buchanan explored the reminiscences of professional Bulgarian musicians (Buchanan 2006), and Anthony Shay analyzed ensembles of several Soviet satellite countries (Shay 2002). At this point I would like to thank Anthony Shay for his positive reaction to my interpretations of the four "contras."

10 We must first become clear about the transformations of traditional dances, that the modification of their context through stage and audience also in other countries and times causes (e.g,, the analysis by Kunej 2006).

11 See also the sociological investigations in Znepolski et al. 2018, the musicological research in Bozhikova 2020; Bix et al. 2005, 2015; Botusharov 1996; Dimov 2001; Peycheva 2008; Naydenova 2017; Statelova 2019; Vulchinova-Chendova 2004; research on the manipulation of dancers in Ilieva 1994; the educational system and the classification of the choreographers in Petrov 2012, 2015; the dance 
Ivaylo Znepolski stated: "For the first time, we have won the right for Bulgarians to talk about the history of Bulgaria, and for such an important and recent period, which is also key to understanding the present." 12

But do the people involved in folk dancing or in dance research hold unambiguous opinions? In addition to my empirical research ${ }^{13}$ and theoretical systematizations, there is much literature about the forms of the genre and their choreographers. The most interesting and provocative contributions to this topic are the differing viewpoints of Anna Ilieva (in her report at the seventeenth symposium of the ICTM study group on ethnochoreology held in 1992 in Greece) and Maria Kurdzhieva (in her 2016 paper written for the Free University of Varna). The established ethnochoreologist faults the ensembles for "brainwashing" professional dancers (Ilieva 1994: 38), whereas her younger colleague criticizes the closure of the professional Varna ensemble in 1991 for having served communist propaganda (Kurdzhieva 2016).

I have devoted a large part of my professional and personal life to analyses of the psychological and semiotic mechanisms of dance as an instrument of manipulation. These will not be explained here in detail and in depth, but I will briefly illustrate the process in the Soviet model. In my opinion, the nature of dance described above made the issue of addressing and resolving the "opposing forms of federal power" (Buchanan 2006: 177) easier for dancers than for people engage in other arts in Bulgaria. Because authentic identity is inherent to dance, it enabled them to experience "the State as Benefactor" (Buchanan 2006: 177). This phenomenon was manipulated on the pragmatic level of Secondness, thus creating dynamic entities of living heritage in the "total musical fact" (Pinto 2018: 82). Just as the totalitarian government wished, the flashy manifestations of Bulgarian folk choreography united villagers and the proletariat, and uplifted and sustained the national spirit of the population. The young, strong, and beautiful dancing bodies on the stage turned into personifications of authentic culture, yet also into symbols of the communist nation.

Right from the beginning, professional "folk" dancing was not only cultivated as an "auto stereotype" (Roth 1996: 65), but also institutionalized as the business card of the People's Republic of Bulgaria abroad. It is precisely in this that I see the subtle political "contra" message of dancing the Bulgarian way following the Soviet model. "Our" professional and masterly performers achieved intoxicating successes and won prestigious prizes at different international festivals, routinely outstripping amateur dance groups from capitalist countries. The use of folkloric choreography to manipulate perception repudiated more

organization in Ivanova-Nyberg 2011; and the many case studies on choreographers and ensembles, e.g., Parlamov 1992, Kurdzhieva 2016, Velemirova 2016.

12 Ivaylo Znepolski, published interview by "24 Chasa”: Izlizamye ot 2018 gu., makar is malko, no poboguati, 2018, available at https://www.24chasa.bg/mnenia/article/7218936.

13 Researching the oral history of the communist period, archival investigation, and exploring video recordings. 
convincingly than any political pronouncements the existence of oppression in Bulgaria and demonstrated an engaging image of the happy communist way of life. ${ }^{14}$

As an insider, ${ }^{15}$ I participated in many private discussions with those involved in the process of creating and performing these impressive and effective productions. I took the opportunity to record their reminiscences and collected a large body of data from the first and most respected choreographers and dance pedagogues, ${ }^{16}$ several prominent composers and arrangers of "folk" dance music, ${ }^{17}$ and a hundred former and current professional dancers. Additionally, during two projects, I interviewed almost two hundred of their contemporary witnesses in Bulgarian villages and towns and more than two hundred from their audiences abroad. In this way I compared the intentions with the effects of intra- and intercultural communication, and I was able to delve deeper into the psychology of the Soviet model. Developing my approach from "reflective participation" 18 to "participatory objectification" (Bourdieu and Wacquant 2017: 287), I became personally aware of the feeling of being an ambassador of one's own country through dance. This is a delightful role, but it sometimes is associated with an innate struggle: a struggle to distinguish the inherent difference between advertisement and actual propaganda in complex political situations, a struggle against clichés and conflicting purposes, and a struggle to accommodate thesis with anti-thesis.

I have no doubt that the Soviet model was conceptualized for the purpose of establishing a unified musical-dance identity of the Bulgarian populace in order to project an image of respect in a difficult and polarizing political era. Initially, the ensembles served as a tool for countering distrust and disapproval of communism. Within the framework of monopolism, the model reached an extremely high artistic level and took advantage of the East-West competition and the corresponding political confrontation very productively and creatively. On the other hand, when crossing the state border, the professional Bulgarian "folk" dance provided an offer for peaceful coexistence and international understanding and acceptance. Through the interpretative strategy of social research (cf. Rosenthal 2005), I realized that many dancers and choreographers found a niche of political freedom that was not just associated with a personal sense of security and conformity. The performers

14 Even as fiction, Lilyana Stefanova's travelogue of the first concert tour of the State Ensemble in North America in 1963 is a fruitful source of information (Stefanova 1989: 9-222). As I also suspect, the author reports that the success of the folk dance performances exceeded the impact of political speeches at the UN (Stefanova 1989: 27-29).

15 I graduated from all the highly acclaimed schools in the genre and after 1988 I was a soloist and later a dance-master of the National Ensemble of Bulgaria.

16 Such as Margarita Dikova, Cyril Djenev, Cyril Haralampiev, Dimitar Dimitrov, Ivan Todorov, Georgi Abrashev, Yordan Yanakiev, Todor Karapchanski, Todor Bekirski, Cyril Apostolov, Christo Ivanov, Nicola Kolev, and Krasimir Petrov.

17 Such as Cyril Stefanov, Nikolay Kaufman, Kosta Kolev, Mihail Yordanov, Mihail Bukureshliev, and Stephan Dragostinov.

18 I have described this in many prior publications (e.g., Panova 1999; Panova-Tekath 2005, 2010, 2018). 
assumed their obligations as representatives of the regime, but preferred to view their role as peacemakers, offering an alternative to the Cold War raging at the time. In this sense, the Soviet model of the phenomenon paved the way for real communication between people on both sides of the Iron Curtain and fulfilled the purpose of an inspiration for the American model and its disseminators. At that time there was no chance for equality and togetherness with the Western foreigners, only the idea of it and hope. Even the "mother" of Bulgarian professional choreography, Margarita Dikova, emphasized in our conversations that besides "the challenge to show what you are capable of," it afforded "the opportunity to meet other peoples on an equal footing." 19

I chose the name of the model because of its origin, but the Bulgarian "folk" choreography gained independence from its role models in the USSR very early (cf. Igor Moiseyev's activity as described in Panova-Tekath 2018). Perhaps that is why the Soviet model of dancing the Bulgarian way and its state ensembles and schools have survived to this day.

\section{THE AMERICAN MODEL: DANCING THE BULGARIAN WAY AS A PRACTICE “CONTRA” TO THE OFFICIAL STATE POLICIES}

The "Balkan Fascination" 20 emerged relatively early on from within the framework of the recreational dance movement in North America, and Bulgarian folklore enjoys special preference there to this day. Since 1994 I have been regularly invited to teach Bulgarian dances abroad, and this has afforded me excellent opportunities to collect a great deal of empiric material and to apply Grounded Theory methods (Glaser and Strauss 1967). In addition to audiovisual data and text files from my surveys, my body of research includes over three hundred individual and group interviews in Europe, almost two hundred in America, and fifty in Asia.

The phenomenon of foreigners dancing Bulgarian traditional circle dances, which its most ardent disseminator, Yves Moreau, ${ }^{21}$ calls the "American model," consolidated itself during the hippie movement in the 1960s and 1970s. Many of my interlocutors began their dancing the Bulgarian way ${ }^{22}$ as a practice contra to official state policies in the U.S. It made reference to both a return to a rural way of life and a love of nature in the advanced industrial age, as well as an active contradistinction from the senseless wars and East-West confrontation.

19 Margarita Dikova, tape-recorded interview in her home in Sofia, Nov. 20th, 1990.

20 I use the term by Mirjana Laušević and recommend her study in order to understand the context of the American model of dancing the Bulgarian way (Laušević 2007).

21 I have referred to Yves Moreau in several other publications (e.g., Panova-Tekath 2014). One of the detailed summaries of the American model can be found in Panova-Tekath 2017.

22 From the beginning of my research I was fascinated with the term used by the German dancers, who refer to it as Bulgarisch Tanzen 'dancing Bulgarian'-like speaking a certain language, and not Tanzen von Bulgarischen Volkstänzen 'dancing Bulgarian folk dances'. 
This is why I claim that the American model of the phenomenon can be viewed as a way of confronting confrontation, as per the Greek philosophers' maxim that negation of the negative leads to positive approbation. ${ }^{23}$ Thus, among many other new activities, dancing the Bulgarian way in its beginnings stood for the famous slogan: "Make love, not war!"

By delving deeper in my study of participation, I deciphered three motivational complexes in the model. ${ }^{24}$ Many of my respondents associated their interest in the dances from Bulgaria with their "curiosity about the way people live behind the Iron curtain," 25 and the dilemma of "who's out there and what actually is happening beyond it." ${ }^{26}$ In North America dancing the Bulgarian way was originally linked with the intelligent younger generation's audacious mistrust in Joseph McCarthy's anti-communist propaganda and its manifestations in the Second Red Scare. Thus, even in the earliest years of the model in American universities, open-mindedness and a right to self-determination became the norm and later also shaped the international folk dance groups in Western Europe, Asia, South America, and finally Australia. Of course, dancing the Bulgarian way would not have been a leisure activity that lasted for decades if it had not also been justified by the fascination of "the incredible exotic music" 27 (Bauer 1995), "the variety of challenging and energetic movements, based on uneven rhythms"28 (Milde 1997; Baechler 2015) or "its ancient roots." 29 The American model created examples of new alternative communities and transcultural identities. It is also important to acknowledge here that it did serve as a vehicle of reconciliation and respect. These virtual "Bulgarian villages" personified a transformative social force and waged a courageous war against absurd political confrontations.

Communication solely through one's own body and the essence of dance conjoined a political statement with self-definition and identity. Step by step, dancing the Bulgarian way lost its exotic character and gained personal authenticity ${ }^{30}$ for many non-Bulgarians. In this way, the phenomenon could not be homogeneous. Its local peculiarities are no less interesting than its general variations of motivational complexes. In German-speaking countries, for example, I recognized one more "contra" aspect of dancing the Bulgarian way related to one's own ethnicity. Bulgarian dances replaced the traditional local repertoire, which was tainted by political misuse. "The legacy of National Socialism made us

23 This is true in mathematics as well; multiplying two negative figures yields a positive result.

24 On three levels they are related to physical challenge, spiritualization, and intercultural communication, but also mark different aspects of social development (Panova 1999; Panova-Tekath 2002, 2005, 2011).

25 Barbara Scharfenberger, tape-recorded interview in Sofia, Bulgaria, August 30, 1998.

26 Debbie Zehnder, tape-recorded interview in Santa Cruz, CA, November 22, 2018.

27 Kurt Bauer, tape-recorded interview in Salzburg, Austria, January 29, 1995.

28 Hansmartin Baechler, tape-recorded interview in Zürich, Switzerland, September 17, 2015; Helwig Milde, tape-recorded interview in Freiburg, Germany, April 18, 1997.

29 Maria-Gabriele Wosien, personal communication, April 23, 1993.

30 I understand authenticity as an expression of one's own identity. 
think that everything German is evil"31 (Brunner 1994). This was how Franz, born in 1935 in Vienna, explained why he practiced Bulgarian dances as a hobby. The traumas of the Second World War made people receptive to a more fluid concept of ethnicity and to the idea of constructing new realities. One of my German interlocutors even claimed, "If I could choose, I would have been born in Bulgaria." 32 The Bulgarian repertoire freed these dancers from their solid, singular ethnicity. In addition, I found several cases in which the aspect of counteraction in the act of folk dancing was clear. For some, the choice to do folk dances from a foreign land deliberately served as resistance to German nationalism and its instruments. "I didn't like dancing German folk dances because I didn't want to be associated with the right-wing political scene," emphasized Ingrid Revering. ${ }^{33}$

Thus, the dancing of Bulgarian folk dances was not only a kind of nonverbal narration about another people and another culture, which performed their "auto stereotype" as a "hetero stereotype" (Roth 1996: 65). It became authentic, and in some cases also transmitted a message of protest against the official policy-against xenophobia and state arrogance — which my interlocutors found painful and embarrassing. More than the other models of the phenomenon, the American model exemplifies reflexive authenticity associated with a fluid form of ethnicity (cf. Panova-Tekath 2010, 2011). However, it has not served egalitarian globalization. Nor has it ever propagated an "ethnolinguistic nationalism" because the dancers shared a common verbal language and "a common descent with those against whom they fought" (Anderson 1991: xii, 47). It was a musical practice of "transculturation" (Pinto 2018: 175-185) ${ }^{34}$ whose inspiration was based in its early years on the ideas of postmodernism and the passion for a "civic nation." ${ }^{35}$ The vision of free and romantic "villages" that it stirs or inflames in its adherents can be interpreted as imaginary communities of "people who honor a common future more than a common past" (Hollinger 1995: 134). In this constellation, the American model of dancing the Bulgarian way, based on an unequivocal respect for Eastern Europe, was not only seemingly, but was in actual practice accessible to individuals from a variety of ethno-racial affiliations.

It opposed discrimination while proclaiming tolerance and a celebration of the differences in the world. This sounds so very up-to-date! Why, then, does the model show signs of aging and have difficulties recruiting members of the younger generation? Concurrently, the Soviet model lost a significant portion of its subsidies, and its scale and social role shrank dramatically. My research points out that one of the reasons for both of these processes is the removal of the Iron Curtain and the overturn of old political power structures.

31 Franz Brunner, questionnaire, December 19, 1994.

32 Barbara Scharfenberger, tape-recorded interview in Sofia, Bulgaria, August 30, 1998.

33 Ingrid Revering, group interview in Rosenheim, Germany, October 30, 2017.

34 Otherwise, I use Welsch's (1992) concept of transcultural communication.

35 There is a huge and long-standing debate in the United States about the civic nation and its multiculturalism. See, e.g., the description of the confrontational positions by David Hollinger (1995). 
After the end of the Cold War and the accession of Bulgaria into the European Union, I have witnessed a grand revival of interest in traditional dancing among the younger generation of Bulgarians both at home and abroad. In its two newly emerging variations, the phenomenon of dancing the Bulgarian way is experiencing an unprecedented boom, which has persisted for a decade.

\section{THE DEMOCRATIC CAPITALIST MODEL: CONCEPTUALIZED IN PRESENT-DAY BULGARIA AS A “CONTRA-HOBBY” AIMED AT COUNTERING PERNICIOUS FOREIGN FADS}

As in the case of the first Bulgarian musical compositions based on folklore, the democratic model of dancing the Bulgarian way made its debut under the slogan of "Let us not yield to foreign influences, but turn back to our own tradition!" I have observed this complex phenomenon since 2007, applying qualitative social research and dance analyses, and here I focus specifically on its characteristics of protest. It is not exactly clear where and when this model was initiated. There are several individuals claiming to be its founders in several different locations. All of them attribute this phenomenon to the (incarnate) fear of the perishing or forfeiting of one's own culture and/or identity. They had in mind "the dangers" 36 that appeared in the times of lost orientation after 1989: a historical period that I interpret as a "floating gap," borrowing the term from Jan Assmann (cf. Panova-Tekath 2010: 257-260). "I reached the realization that if we didn't do something, we would be overtaken by the Chalga and the Latino," recalls Eva Delinesheva, ${ }^{37}$ and this is a reminder of the time when the prominent American ethnomusicologist Timothy Rice posed the question "Bulgaria or Chalgaria?" (Rice 2002). Lo and behold, the "contra" not only marches side-by-side with the affirmation of "one's own," but it is its main driving force.

In its essence today, the prevailing model is not centralized but is multifaceted, flexible, and commercialized. This means that the national image does not work as an "autopilot that automatically keeps a plane on course" (Assmann 2018: 77). Consciously or not, it underwent an inspection. Its critical revision revived the ancient form of the social circle dance, while its advertising strategies were based on each individual's perceptions. In this way, the phenomenon achieved a greater popular response even compared to that in the communist era. There is not a residential quarter in Bulgaria without a folk dance club and there is not a city without a horoteque instead of a discotheque! The number of festivals and out-dance events has increased immensely over the years. Many new people "come because it's the fashion today, but then the dance grabs them and it becomes a passion." ${ }^{38}$

36 Galina Gavrailova, tape-recorded interview in Balchik, Bulgaria, August 23, 2018.

37 Evelina Delinesheva, video-recorded interview in Sofia, July 11, 2012.

38 Petya Ilieva, online interview, March 31, 2020. 
Interestingly, the personal reflexive authenticity of the dancers in this model is very connected with the term for authenticity of the solid culture. In 2020, there are many discussions and confrontations within the arts about right and wrong names, "authentic" and "not authentic," Bulgarian or not, best teaching, oldest variation, and so on, which are particularly fought out online. In addition to all the open forums, closed Facebook groups such as "Treasury of the Bulgarian hora ${ }^{39}$ and dances" 40 and "In love with the horo" ${ }^{41}$ offer their more than five thousand members an attractive platform for fruitful communication. This time around, dancing the Bulgarian way is not an implementation of a directive from higher up, but the result of a presumably natural need for culture ${ }^{42}$ from below. Even if in the context of emerging capitalism it is very quickly intertwining with business, it acts as a social framework in the sense of Maurice Halbwachs' understanding of cultural memory (1985). Its new political power with a nationalistic flair is founded on a local antithesis to globalism within the European Union. Globalization is rejected, because hundreds of dancing Bulgarians view it as arrogance in the sense of Zygmunt Bauman's theories ${ }^{43}$ and see in it mostly assimilatory ambitions on the part of the larger countries. Even when the dancers are positively inclined toward the West, they still fear the presumed absence of cultural identities and contours in globalism as such. Focusing on the individual level, this is then not far removed from Safranski's question: "How much globalization can a human endure?" (2006). Basically, all models of dancing the Bulgarian way are its rhetorical counter-stance. Ivan Spasov, who is only 16 years old, explains the democratic model:

We saw that the culture of Europe was not what we expected, and we decided to look for the different in ourselves, and we got a return to the past that takes people out of their busy lives... . Now the population is divided into two groups: 1. imitating the West, and 2. seeking oneself in oneself. ${ }^{44}$

Today, Bulgarian dances not only take the form of an edifice of the common heritage, but also vitalize the national pride and the memory of the liberation struggles that form a part of it. The model supports Bulgaria's political claim to being an autonomous historical subject in Europe and helps individuals in their self-assertion.

\footnotetext{
39 Horo (hora pl.): traditional circle dance.

40 Sikrovishtnitza za bjlguarski khora i tantzi, established July 7, 2013 by Misho Kadiev.

41 Vlyobyeni $v$ khoroto, established August 21, 2019 by Radka Matsanova.

42 Radka Matsanova, online interview, March 30, 2020.

43 See the description of "global people" in Bauman 1998.

44 Ivan Spasov, online interview, March 29, 2020.
} 


\section{THE EMIGRANT MODEL: CURRENTLY BLOSSOMING AS A “CONTRA- CULTURE" OR OPPOSITION TO ALL REAL OR CHIMERICAL ASSIMILATORY TENDENCIES}

Traditional dancing among the Bulgarian diaspora has also been experiencing a major surge over the last decade. Having lived abroad for twenty-five years, I have used the opportunity to observe and study the development in Bulgarian diasporas as an insider in Europe, North America, and Japan. The boom in the model I explain springs not from the changing contexts of the host countries, but from the fact that there is currently a new type of massive flow of Bulgarian emigres to foreign lands, which in its essence is not politically but economically motivated. The vanguard of the emigrant model is well-educated and highly-qualified people in their forties with a pronounced sense of national pride, which they do not hide and do not intend to sacrifice while in their new habitat. Similar to the ambivalence in other Eastern European diasporas, the young Bulgarian emigres differ from and are not overly well received by the older generation of emigres, who were mostly refugees escaping communism. Against the background of this subtle and almost indiscernible confrontation, the young Bulgarian diaspora prefers to set up its own communities, schools, and folk dance groups.

Their ties with the motherland are both active and flexible. The younger diaspora tends to first familiarize itself with the traditional village style social circle dances, practiced as part of the democratic model. Gradually those folklore forms become replaced with stage choreographies derived from the Soviet model. My explanation of this specific evolutionary process is founded on the assumption that one of the first needs of the emigrants is to find, unite, and consolidate their "own" within the predominant local cultural environment. Then the expression and experience of the dancing leads to a more courageous entry on the scene and engagement in intercultural communication with it. This is the logical way of conjoining "expression" with "appeal" and "performance" as per Carl Buehler's formulation in the Organon model (cf. Panova-Tekath 2011). The act of metamorphosis does not efface the "contra" idea in the phenomenon, because many of the practitioners maintain that this is the only way to dissociate from and demonstrate to the host country who we are. ${ }^{45}$

Practicing the American model of dancing the Bulgarian way in the same location does not necessarily lead to active association, inclusion, or unification. On the contrary, some of the new Bulgarian emigrants, after having met with the local international folk dance groups, tend to be motivated to disassociate from them, with the aim of learning, on their own, more about their national folklore: We visited Café Aman, with a feeling of superiority, but then it turned out that the local Americans dance better and more Bulgarian

45 Evelina Pencheva, personal communication, May 20, 2019; Monika Vuleva, tape-recorded interview in Montreal, Canada, March 26, 2012. 
folk dances than us! How come? This cannot be! ${ }^{46}$ This feeling of national dignity motivated many of the Bulgarian women married to Germans, living in Essen, to turn to me as early as 1995 (long before the emigrant model of dancing the Bulgarian way made its debut), to teach them "our" national folk dances separate from my open workshops. As John Filcic recalls, in the 1930s the old Bulgarian diaspora also made use of venues earmarked for its vecherinki 'soirées', collaborating only with Macedonians in Pittsburgh, Portland, San Francisco, Los Angeles, and other cities. ${ }^{47}$

It is remarkable that in both the case of the democratic and the new emigrant models there are numerous participants, who years earlier would never even have imagined that at some point in time they would begin to like folk dancing. Yet, today it has become a part of their everyday lives. Moreover, they are proud to dress in Bulgarian folk costumes, learn to play the bagpipe or drums, apply folklore rituals when celebrating with their children, and so on. In their case "tradition" has become the equivalent of "innovation," whereby monoculture is the offspring of multiculturalism.

To top it all off, there is not an element of confrontation with the acknowledged authorities of the dance ensembles of the communist period. Prominent choreographers and former professional performers are admired and accepted as leading proponents of the emigrant model. This is more evident in America than in Europe: the farther the new Bulgarian diaspora lives from the homeland, the more markedly the "folk" dance expertise from the communist past is appreciated. There are many signs of this sudden appreciation on the other side of the Atlantic, including, but not limited to, an emphatic recognition of the old dance and music professionals as special guests, online reviewers, teachers, and master-choreographers. Those professionals that also emigrated lead the most successful Bulgarian ensembles and festivals in North America, and the young community honors and follows them as its elite. In Western Europe there is a more marked interest in the young leaders and activists of the democratic model, who are often invited to teach or just to support the emigrant dance groups as performers at various events. Several visitors and friends from Bulgaria, along with sixty-one groups of emigres, attended the largest festival of the European diaspora, "Na megdana na drugata Bŭlgariya" 'On the dance square of the other Bulgaria', held in 2019 in La Nucia, Spain. ${ }^{48}$ The name of the festival is noteworthy for the way it positions Bulgaria in the world. According to one of its founders and a leader of the Bulgarian community in Lyon, France, the name On the dance square of the other Bulgaria" is "not because we wanted to say that we are different. No, we are the

46 Daniela Bojidarova, video-recorded interview in Los Angeles, CA, April 4, 2016.

47 John Filcic, video-recorded interview in Stockton, CA, August 1, 2019. At this point it would be interesting to compare it to the Slovenian dances in America, which musically differentiated between the events of the immigrant communities and those of the local recreational Folk Dance Federations (Ivancich Dunin 2015) and perform in a different way to the dance ensembles in the homeland (Kunej and Kunej 2016).

48 This festival has been held in various European cities for five years. 
same! But there are many possible other places where Bulgaria will always exist. ${ }^{49}$ Obviously, the emigrant model of dancing the Bulgarian way does not need the cultural environment of the homeland for its collective memory, "because we always carry a number of distinctive people with and within us" (Halbwachs 1985: 2). 50 "Escape can only be understood through movement," wrote Iliya Trojanov (2017: 71). Nevertheless, I have the feeling that the Bulgarian dancing diaspora is not only struggling to outline its own territory, but also countering the claim that "the sedentary people will never understand the nomads" (ibid.).

\section{TOWARD A CONCLUSION: THE SPECIFIC AND THE UNIVERSAL "CONTRA"}

The specific ways Bulgarians and foreigners have adapted traditional Bulgarian dances to create meaning in different eras and countries show how aspects of contrariness and protest arise as part of the authentic enjoyment of dance. The natural human quest for identity involves actions and attitudes that balance and counteract historical and contemporary contexts and create change, yet the very old Bulgarian dances endure as a base for community and individual expression.

After analyzing my interviews with Bulgarian participants, I have come to the insight that resistance is the crux of the historical image of traditional Bulgarian dance. Among these people of different professional, individual, and social backgrounds, there pervades a vision of folklore as the factor that has preserved the nation during centuries of foreign occupation and influence. This semantic specification creates political power that need not necessarily serve a particular government. Therefore, when "folk" dance was sponsored by the Bulgarian Communist Party, the interpretation of it as a means of cultural survival and human respect was stronger and more sustainable than its connection to ideological propaganda. This old image of folklore is one of the main reasons Bulgarians' attitude vis-à-vis traditional dancing remained positive, even after 1989, and differed considerably from the attitude I encountered in German-speaking countries after 1945.

It is too early to objectively assess all facets of the development of today's urban dancing the Bulgarian way, because several group leaders in the two new models have benefited from the communist past and firmly oppose any criticism of the Soviet model. However, my biographical studies show a remarkable continuity in the reflection of "folk" dance as a symbol of a desirable Bulgaria. Because its choreographies are also declared the central marker of national identity, they provoke expressions of extremely high self-confidence and self-admiration among some Bulgarians: we have the best, richest and most beautiful dance

49 Anita Ekenova, video-recorded interviewed in La Nucia, Spain, May 12, 2019.

50 The Bulgarian diaspora is still very young and small compared to other ethnic minorities in Western European countries. Nevertheless, its dance practice seeking for memories already makes it possible to maintain a degree of cultural continuity (cf. David 2015). 
culture in the world. . . no other people are so talented, emotional, and able to spread their tradition around the world and to preserve it so well. ${ }^{51}$ But it would appear that such cultural narcissism is not unique in the area of folk dancing and singing. According to folklore, the most beautiful women and strongest men in the world live in every region. Fortunately, this ethnocentrism has yet not crossed the line into pathology in Bulgaria and the "contra" embedded in dancing has never combined self-affirmation with aggression.

Nowadays there is a vigorous debate about the authenticity of Bulgarian dances. The controversies in all models about which dances are the real Bulgarian ones, how much they should be updated, and who has the right to teach them could be the subject of a separate article. Here I have highlighted authenticity as an expression of the identity of the person or persons dancing. I have also examined the attitudes to sociopolitical contexts that forced the construction of new communities and cultural realities.

Thus far, I have focused on the gentle protest inherent to the four models of the phenomenon that some participants either intended or came to recognize as time passed. At first glance, the political message of adapting old Bulgarian dance forms to new contexts is not conspicuous and not unambiguous. Each of the "contras" manifests itself differently by dancers in different geopolitical locations and times, but one thing is common to the protests of all models: their existential character. Dance transmits identity, whereas identities survive by drawing boundaries. These boundaries are essentially a form of "contra." Dancing the Bulgarian way is always associated with communication and (re)construction processes. The first two models emerged as a quest for identity in the situation of East-West competition before 1989, whereas the next two models established themselves as a struggle to preserve identity amidst homogenization.

Analyzing this communication yields two distinct crystallizations: that the three Bulgarian models contain in their inherent monocultural alphabet a language that enables them to participate in the multicultural world, and the American model of the phenomenon confronts polarizations and seeks out new transcultural spaces. Thus, within the paradigms of neo-traditionalism and postmodernism, dancing the Bulgarian way exemplifies and constantly combines the "contra-culture" of identity with the common-to-all-mankind "pro-culture."

What guarantees the future existence of the phenomenon and makes it interesting to study? The persistence of people gathering over the years to dance Bulgarian dances is related not only to the demonstration of one's heritage but also to the general idea of surviving respectfully in dynamic sociopolitical contexts. All four "contras" I have described successfully navigate between cultural and communicative memory and serve as a link between the tenacity of the Bulgarian monuments and the flexible variety of requirements

51 N. Krasimira, online interview, March 31, 2020. There were many similar comments in my questionnaires and private conversations from 1976-2020, but I prefer not to disclose these individuals' names. 
inherent to life as such. The intra- and intercultural interaction between highly interpretative people develops reflexive authenticity and creates a kind of fluid ethnicity or nationality.

Today, no one doubts the "communicative power" 52 of the phenomenon for the two Bulgarias — the "Bulgaria as it is" and "the other Bulgaria" — as well as for open-minded people from all over the world. The Soviet model overrode the attributes of communism, the democratic model strengthens diversity in Europe, and the emigrant model protects against assimilation during seamless integration. Hopefully, the American model will come forth with new representatives from the younger generation, which will oppose the current right-wing populism and neonationalism in the world.

It is always surprising how much the gentle protest of traditional urban dance can change and achieve. In times like the coronavirus crisis of 2020-without political confrontations, but with other serious problems - dancing the Bulgarian way again plays an important role in people's lives as a "counter-authority." Without actually dancing in the same place together, the phenomenon gathers participants from all of the models listed, from far-flung parts of the world, introduces them to each other online and helps them to build and stabilize even larger communities than before. Through the use of the internet, people are deepening the intracultural and transcultural discussions about the cornerstones of the Bulgarian tradition and are experiencing the potential of Bulgarian dance as uplifting encouragement and as resistance to social separation. Through fascinating old films, online lessons, and virtual dance parties, the phenomenon of dancing the Bulgarian way continues as a survival strategy and ongoing definition of what is authentic and meaningful to individuals and groups in many contexts. Ultimately, the "contra" turns into a confirmation of life.

\section{REFERENCES}

Anderson, Benedict. 1991. Imagined Communities: Reflections on the Origin and Spread of Nationalism. New York: Verso.

Assmann, Aleida. 2018. Der Europäische Traum: Vier Lehren aus der Geschichte. Munich: Beck.

Bauman, Zygmunt. 1998. Globalization: The Human Consequences. New York: Columbia University Press.

Bix, Rosalia et al. 2005. Bŭlgarski muzikalen teatŭr: Opera, Balet, Opereta, Myuzikŭl (Teatri, Trupi, Postanovki), 1890-2005. Sofiya: Bŭlgarska akademiia na naukite.

Bix, Rosalia et al. 2015. Bŭlgarski muzikalen teatŭr: Opera, Balet, Opereta, Myuzikŭl (Retsenzii, Otzivi, Komentari), 1890-2010. Sofiya: Marin Drinov/Geya-Libris.

Botusharov, Lyuben. 1996. Razkovnicheto e stilŭt. Bŭlgarsko muzikoznanie = Bulgarian Musicology 20 (4): $80-84$.

Bourdieu, Pierre, and Loïc J. D. Wacquant. 2017 (1992). Reflexive Anthropologie. Frankfurt am Main: Suhrkamp.

52 An important term in Joe Reichertz's theory (Keller et al. 2013: 49-68). 
Bozhikova, Milena (ed.). 2020. Music between Ontology and Ideology. Cambridge: Cambridge Scholars Publishing.

Buchanan, Donna A. 2006. Performing Democracy: Bulgarian Music and Musicians in Transition. Chicago: University of Chicago Press.

Buchler, Justus (ed.). 2014. The Philosophy of Peirce: Selected Writings. London, New York: Routledge.

Cassirer, Ernst. 2010 (1923-1929). Philosophie der Symbolischen Formen. Vol. 1-3. Hamburg: Meiner.

David, Ann R. 2015. Embodied Cultural Memories of the Punjab: 'Giddha' Dance and Song in Migrant London Spaces. Traditiones 44 (2): 149-171. DOI: https://doi.org/10.3986/Traditio2015440208.

Dimov, Ventsislav. 2001. Etnopopbumŭt. Sofia: Bŭlgarsko Muzikoznanie Izsledvaniya.

Djudjev, Stoyan. 1932. Narodna i khudozhestvena muzika. Rodna Pesen 5 (4): 100-101.

Ferrara, Alessandro. 1998. Reflective Authenticity: Rethinking the Project of Modernity. London and New York: Routledge.

Glaser, Barney G., and Anselm L. Strauss. 1967. The Discovery of Grounded Theory: Strategiesfor Qualitative Research. Chicago IL: Aldine.

Halbwachs, Maurice. 1985 (1925). Das kollektive Gedächtnis. Frankfurt am Main: Fischer.

Hollinger, David A. 1995. Postethnic America: Beyond Multiculturalism. New York: BasicBooks.

Ilieva, Anna. 1994. Bulgarian Folk Dance in the Past 45 Years. In: Irene Loutzaki (ed.), ICTM 17th Symposium of the Study Group on Ethnochoreology 1992, Proceedings. Nafplion: Peloponnesian Folklore Foundation and ICTMC, 35-38.

Ivancich Dunin, Elsie. 2015. Slovenian Dances and Their Sources in California. Traditiones 44 (2): 73-90. DOI: https://doi.org/10.3986/Traditio2015440204.

Ivanova-Nyberg, Daniela. 2011. Sŭstavŭt za narodni tantsi kato kulturno yavlenie. Sofiya: Mars-09.

Keller, Reiner et al. (eds.). 2013. Kommunikativer Konstruktivismus: Theoretische und empirische Arbeiten zu einem neuen wissenssoziologischen Ansatz. Wiesbaden: Springer Fachmedien.

Kunej, Rebeka. 2006. Transformacije ljudskega plesa v predstavitvah za 'druge': Primer treh kol iz Bele Krajine. Traditiones 35 (1): 123-134. DOI: https://doi.org/10.3986/Traditio2006350106.

Kunej, Rebeka, and Drago Kunej. 2016. Folklorna skupina v diaspori: Soočanje tradicije in ustvarjalnosti v Ameriki. Etnolog 26: 49-64.

Kurdzhieva, Maria. 2016. Ansambŭl za narodni pesni i tantsi 'Varna' - emblema v kulturnata istoriya na Varna. Kulturnoto nasledstvo na Varna. Izvestiya na sŭyuza na uchenite. Varna: CU.

Laušević, Mirjana. 2007. Balkan Fascination: Creating an Alternative Music Culture in America. Oxford: Oxford University Press.

McNeill, William H. 1997. Keeping Together in Time: Dance and Drill in Human History. Cambridge: Harvard University Press.

Naydenova, Goritsa. 2017. Agitki, khorove i sedenki: pŭrvoto desetiletie na upravlyavanata khudozhestvena samodeĭnost v Bŭlgariya (1944-1954). Bŭlgarsko muzikoznanie = Bulgarian Musicology 41 (1):20-44.

Panova, Gergana. 1999. Der bulgarische Volkstanz: Ein altes Abgrenzugsinstrument dient heute der Integration. Bŭlgarsko muzikoznanie = Bulgarian Musicology (23) 2:136-148.

Panova-Tekath, Gergana. 2002. The Bulgarian Folk Dances at Home and Abroad. Studia Choreologica 4: 101-146. 
Panova-Tekath, Gergana. 2005. Kommunikations-choreologische Forschungen im neuen Europa: Über die Identität im Übergang. Bŭlgarsko muzikoznanie = Bulgarian Musicology (29) 3:37-71.

Panova-Tekath, Gergana. 2010. Tanz nach der Wende: Der Körper alssymbolische Form. Vol. 1. Essen: Klartext.

Panova-Tekath, Gergana. 2011. Tanz nach der Wende: Die 'Volks'-Choreographie als symbolische Kommunikation: Vol. 2. Essen: Klartex.

Panova-Tekath, Gergana. 2014. Identities in Motion: 60 Years Dancing the Bulgarian Way within Different Political contexts. Papers of the Bulgarian Academy of Sciences. Humanities \& Social Sciences 1 (1): 44-58 (in English), 47-59 (in Bulgarian).

Panova-Tekath, Gergana. 2015. Cultural Heritage between East and West, Continuity and Innovation, Body and Spirit. In: Elsie Dunin (ed.), Dance, Narratives, Heritage: Dance and Narratives: Dance as Intangible and Tangible Cultural Heritage: 28th Symposium of the ICTM Study Group on Ethnochoreology, 7-17 July 2014, Korčula, Croatia. Zagreb: Institute of Ethnology and Folklore Research, 330-335.

Panova-Tekath, Gergana. 2017. Komunikatsiya, adaptatsiya, integratsiya: Bŭlgarskiyat tants v dve epokhi na chetiri kontinenta. Novi teoretichni razmisli. Bülgarsko muzikoznanie = Bulgarian Musicology 41 (3-4): 98-120, 200.

Panova-Tekath, Gergana. 2018. At the Crossroads: The Transformation of Dance Folklore into a Professional Stage Art in Bulgaria in the Second Half of the Twentieth Century. In: Daniela Stavělová and Theresa Jill Buckland (eds.), Folklore Revival Movements in Europe Post 1950: Shifting Contexts and Perspectives. Prague: Institute of Ethnology of the Czech Academy of Sciences, 191-215.

Parkin, David. 1996. The Power of the Bizarre. In: David Parkin et al. (eds.),The Politics of Cultural Performance. Vols. xv-xl. Oxford: Berghahn.

Parlamov, Ivan. 1992. Khoreomaǐstorŭt, ili Tantsŭt e prezhivyavane. Plovdiv: Slivenski.

Petrov, Krassimir. 2012. Prinosŭt na bŭlgarskite khoreografi za stsenichnoto presŭzdavane na narodnite tantsi: Vol. 1. Sofiya: Slavena.

Petrov, Krassimir. 2015. Prinosŭt na bülgarskite khoreografi za stsenichnoto presŭzdavane na narodnite tantsi: Vol. 2. Sofiya: Slavena.

Peycheva, Lozanka. 2008. Mezhdu seloto i Vselenata: Starata folklorna muzika ot Bŭlgariya v novite vremena. Sofiya: M. Drinov.

Pinto, Tiago de Oliveira. 2018. Music as Living Heritage: An Essay on Intangible Culture. Berlin: EMVAS.

Rice, Timothy. 2002. Bulgaria or Chalgaria: The Attenuation of Bulgarian Nationalism in Mass-Mediated Popular Music. Yearbook for Traditional Music 34: 25-46.

Rice, Timothy. 2004. Music in Bulgaria: Experiencing Music, Expressing Culture. New York: Oxford University Press.

Rosenthal, Gabriele. 2005. Interpretative Sozialforschung. Weinheim und München: Juventa.

Roth, Klaus. 1996. Erzählen und Interkulturelle Kommunikation. In: Klaus Roth (ed.), Mit der Differenz leben: Europäische Ethnologie und Interkulturelle Kommunikation. Münster, Munchen and New: Waxmann, 63-78.

Safranski, Rüdiger. 2006. Wie viel Globalisierung verträgt der Mensch? Frankfurt am Main: Fischer.

Shay, Anthony. 2002. Choreographic Politics: State Folk Dance Companies, Representation and Power. Middletown: Wesleyan University Press.

Statelova, Rozmari. 2019. Estrada i sotsializŭm: Problyasŭtsi. Sofiya: Riva.

Stefanova, Lilyana. 1989. Nepovtorimoto. Sofiya: Narodna Mladezh. 
Trojanov, Ilija. 2017. Nach der Flucht. Frankfurt am Main: Fischer.

Velemirova, Gergana. 2016. V ritŭma na sürtseto: Zhivot v magiyata na rodniya tants. Burgas: Baltika 2002.

Vulchinova-Chendova, Elisaveta. 2004. Novata bülgarska muzika prez poslednite desetiletiya: Modeli i interpretatsii. Sofiya: Bŭlgarska akademiia na naukite.

Welsch, Wolfgang. 1992. Transkulturalität - Lebensformen nach der Auflösung der Kulturen. Information Philosophie (20) 2: 5-20.

Znepolski, Ivaylo et al. 2018. Bulgaria under Communism. London: Taylor \& Francis

\section{ŠTIRJE "PROTI« ČASI: \\ SOVJETSKI, AMERIŠKI, DEMOKRATIČNI IN EMIGRANTSKI MODELI PLESA NA BOLGARSKI NAČIN}

Širjenje "bolgarskih ljudskih plesov" $v$ urbanih središčih pred in po letu 1989 je večplastna tema, ki jo avtorica raziskuje že dlje časa. V članku predstavlja novo stališce do štirih modelov "plesa na bolgarski način" tako Bolgarov kot tujcev, pri čemer se posebej posveti elementu protesta, lastnemu vsem modelom. S kvalitativnimi raziskavami je odkrila, da vsak element "proti « spodbuja procese samoopredelitve plesalcev, oblikovanje skupnosti in povezanost določene simbolike s politično močjo.

1. Učinek bleščečih profesionalnih "ljudskih" koreografij v okviru sovjetskega modela je močno presegel upliv uradnih političnih govorov $v$ dobi tekmovanja in konfrontacije med vzhodom in zahodom. Hkrati pa so lahko bolgarski izvajalci ustvarili nišo relativne politične svobode in se v tej vlogi dojemali kot kulturni veleposlaniki in mirovniki.

2. Ameriški model se je utrdil v časih hipijevskega gibanja v 60. in 70. letih prejšnjega stoletja. Na eni strani je bil neverbalna pripoved o drugi kulturi, na drugi pa protest proti državni politiki, proti ksenofobiji in aroganci države.

3. Demokratični kapitalistični model se je brez kakršne koli direktive od "zgoraj navzdol" razcvetel v današnji Bolgariji kot hobi, namenjen boju proti škodljivim tujim modam. Njegova politična moč temelji predvsem na lokalni protitezi globalizmu v Evropski uniji in se opira na politično tezo, da je Bolgarija samostojen zgodovinski subjekt.

4. Z emigrantskim modelom se je nova bolgarska diaspora odkrila, poenotila in hkrati utrdila v prevladujočem drugačnem lokalnem kulturnem okolju; s tem se je opogumila, da se povzpne na oder in se vključi v medkulturno komunikacijo.

Avtentičnost plesa je v tem času postala predmet refleksije, nacionalna pripadnost pa fluiden koncept. V konstrukciji različnih resničnosti bolgarski kulturni mit ni več uporaben kot "avtopilot«, ampak je vir za doseganje sodobnih ciljev. Ples na bolgarski način tako ni več predstava, ki jo je mogoče opredeliti kot "spominski ali spravni kič", temveč je prispevek k novim 
FOUR TIMES “CONTRA”: THE SOVIET, AMERICAN, DEMOCRATIC, AND EMIGRANT MODELS OF DANCING ...

"sanjam o Evropi« in svetu po hladni vojni in širše in hkrati mehka preživetvena strategija; na spletu nadaljuje svojo vlogo kot upor kot novo "nasprotje« koronski krizi.

Assoc. Prof. Dr. Gergana Panova-Tekath

Institute for Art Studies, Bulgarian Academy of Sciences

Sofia, Bulgaria,

and

Folkwang University of Arts

Schlossstr. 132, D - 45355 Essen, Germany, gerganafolkwang@gmail.com. 